\title{
Public policy for academic entrepreneurship initiatives: a review and critical discussion
}

\author{
Christian Sandström ${ }^{1,2}$ (D) Karl Wennberg ${ }^{2,3}$ (D) \\ Martin W. Wallin ${ }^{1}$ (D) Yulia Zherlygina ${ }^{2}$
}

Published online: 1 December 2016

(C) The Author(s) 2016. This article is published with open access at Springerlink.com

\begin{abstract}
This article provides a critical review and discussion of current literature on technology transfer, incubators, and academic entrepreneurship. Drawing upon the notion of robustness in social systems and public choice theory, we review, code, and taxonomize 166 studies to assess the likelihood that these initiatives will generate innovation and economic growth. We find that academic entrepreneurship initiatives are characterized by conflicting goals, weak incentive structures for universities and academics, and are contextually dependent upon factors such as university strength. Our results suggest that there are critical boundary conditions that are unlikely to be fulfilled when universities and policymakers enact policies to support academic entrepreneurship initiatives. Policymakers therefore need to be cautious in the potential design of such initiatives. We discuss how technology transfer from universities might be better achieved through alternative mechanisms such as contract research, licensing, consulting and increased labor mobility among researchers.
\end{abstract}

Electronic supplementary material The online version of this article (doi:10.1007/s10961-016-9536-x) contains supplementary material, which is available to authorized users.

\section{Karl Wennberg}

Karl.Wennberg@liu.se;

https://liu.se/ias/medarbetare/wennberg-karl/presentation?l=en\&sc=true

Christian Sandström

christian.Sandstrom@ratio.se

Martin W. Wallin

martin.wallin@chalmers.se

Yulia Zherlygina

yulia.zherlygina@ratio.se

1 Chalmers University of Technology, 41296 Gothenburg, Sweden

2 The Ratio Institute, P.O. Box 3203, 10364 Stockholm, Sweden

3 Department of Management and Engineering (IEI), Linköping University, Linköping, Sweden 
Keywords Academic entrepreneurship - Literature review · Policy · Robustness · Public choice theory

JEL Classification O3 $\cdot$ M13 $\cdot$ O4

\section{Introduction}

Over the past decades, academic entrepreneurship—loosely defined as initiatives aimed to generate entrepreneurial ventures from university research (Grimaldi et al. 2011)-has been highlighted as an important catalyst of innovation and economic growth (Etzkowitz and Klofsten 2005). This trend has been accompanied by an expanded strategic scope of universities. Universities are no longer regarded as only providers of basic research and skilled labor but increasingly thought of as engines for regional and national growth with a mandate to innovate and build businesses (Shane 2004b; Etzkowitz 2003). Not surprisingly, policymakers and academic institutions have invested extensively in initiatives for commercialization of academic research (Link et al. 2014). University management increasingly highlight 'impact' as one of the overarching goals of universities (Gast 2015). Yet, it remains unclear to what extent commercialization initiatives to support academic entrepreneurship are an effective and efficient way to enhance innovation and growth.

Efforts to promote academic entrepreneurship (from here on 'AE') has been the focus of much empirical and theoretical research, exploring e.g. best practices of policy interventions (Rothaermel et al. 2007), antecedents and enabling factors of commercialization (Perkmann et al. 2013) or specific transfer mechanisms such as university spinouts (Djokovic and Souitaris 2008). These prior syntheses adopt an efficiency-enhancing perspective sprung from a market failure analysis. Put differently, they are concerned with fine-tuning an established system rather than assessing its general effectiveness. A critical assessment of those AE initiatives that seek to address such market failures is therefore warranted. From a market failure perspective, firms are believed to underinvest in 'good' university research with commercial potential because of appropriability problems (Martin and Scott 2000); policies are then devised to 'correct' the failure—often by incentivising universities to actively partake in promoting entrepreneurial ventures. In other words, these AE initiatives should remove obstacles the market cannot handle on its own, thereby improving the efficiency by which universities transfer knowledge and spin out technologies.

In this paper however, we depart from the efficiency-focus of previous work, take a critical stance, and instead ask how effective AE initiatives are. An efficient system can be regarded as one that transforms input into output in a resourceful manner. The notion of effectiveness rather refers to whether the overall system fulfils its purpose or not. This is a different approach as it allows us to discuss how likely $\mathrm{AE}$ is to actually generate the intended benefits and to correct market failure in a cost-effective manner. A focus on effectiveness rather than efficiency may very well lead to different conclusions as to what constitutes 'good' AE initiatives. For example, a policy that induces professors to commercialize their research findings may be highly efficient in creating new ventures but at the same time be societally wasteful. How can that be? Consider a situation where an AE initiative incentivizes professors to commercialize substandard technologies. A likely result is many new university spin-offs but few growing companies, and a decrease in university research capacity when researchers leave their main activity. Or consider the alternative situation where publicly funded $\mathrm{AE}$ initiatives incentivize professors pursuing 
world-class research to take their findings to the market. A likely result is that public money will crowd out private investments. The crux of the matter is the following: AE initiatives that are efficient in transferring academic knowledge may not necessarily increase overall societal welfare. How can we understand and analyse these challenges in a systematic manner?

Public choice theory (Buchanan and Tullock 1962; Downs 1957; Tullock 1989) provides a powerful lens to assess $\mathrm{AE}$ initiatives, because it equips us with the methods and tools of economics to explore the effectiveness of policy interventions under conditions of divergent incentives, conflicting goals and opportunistic behaviour, which we refer to 'policy robustness'. We start with an assumption that policy environments are commonly far from optimal - only then do we proceed to examine the effectiveness of AE initiatives (Bergek and Norrman 2008). Specifically, we ask: What are the conditions under which academic entrepreneurship initiatives are more or less successful? Relatedly, we assess to what extent these conditions are likely to be fulfilled or not? Our method is a systematic literature review of the AE field of research, analysing the outcome of interventions such as business incubators, Technology Transfer Offices (TTO) and University spin-offs (USOs).

Our review reveals that the efficiency and effectiveness of AE initiatives is contingent upon several criteria that are in many cases unlikely to be fulfilled. These include e.g. the incentives and capabilities of researchers, adequate design of structures such as TTOs, and institutional setting of the nation, region, university or even department studied. We therefore argue that many $\mathrm{AE}$ initiatives lack robustness as the outcome is highly dependent on a set of boundary conditions that are in many cases unlikely to be fulfilled. This finding has implications, both for future research and for policymakers who seek to foster economic growth by promoting AE initiatives.

We contribute to the literature on academic entrepreneurship by critically reviewing the literature from a public choice perspective, highlighting key limitations in efficiency and effectiveness of AE initiatives, and using these insights to suggest a conceptual model for robust $\mathrm{AE}$ initiatives. The model illustrates how $\mathrm{AE}$ initiatives are contingent upon their ability to activate and align key stakeholders when commercializing academic knowledge. We argue that successful policy formulation and implementation is a matter of adhering to the limitations imposed by boundary conditions and aligning the capabilities and incentives of key stakeholders. Implications for research are discussed where we identify other, potentially more effective means to accomplish positive externalities from universities that hold equal or stronger empirical support in generating innovation and economic development at large.

In the next section we turn to various bodies of literature giving support to the enactment of academic entrepreneurship. The subsequent section contains a description of the method employed, which is followed by analysis and a discussion of these. Towards the end, a discussion and a conclusive remark is provided.

\section{Theoretical rationales for academic entrepreneurship initiatives}

Universities have over the past decades obtained a new and expanded role. Increasingly, they are not only thought of as providers of basic research and graduates but considered as vehicles for regional development and policymakers try to promote growth and innovation through the higher education sector (Shane 2004b). This trend has theoretical foundations in the public goods nature of university research where investments in research and 
innovation are seen as crucial for economic growth and increases in productivity (Hall et al. 2009; Romer 1990; Wieser 2005). The knowledge emanating from university research is often seen as resulting in positive externalities (Audretsch and Lehmann 2005), thus exhibiting some characteristics of a 'public good'. A public good can be defined as a good that is non-rival in its usage and is non-exclusive (Acs 2002). Once acquired, knowledge can be re-used infinitely and one actor cannot stop another one from also using it. These properties of knowledge imply that an economy may benefit extensively from investments in knowledge development, as it tends to spill over into the economy. Yet, when knowledge is tacit and harder to transfer across long distances, the positive externalities become concentrated to the geographical proximity-a situation known as localized knowledge spillovers (Audretsch and Feldman 1996). A sub-stream of this literature has devoted special attention to spillovers from universities (Audretsch and Lehmann 2005; Jaffe 1989; Leyden and Link 2013; Wennberg et al. 2011). This particular characteristic of knowledge as a public good does however imply that markets are likely to undersupply it. The theoretical motivation for public investments stems from the notion that if the benefits of new knowledge are distributed beyond those who developed it, a market economy may generate a sub-optimal amount of research and innovation (Arrow 1962). Public support schemes and other mechanisms supporting AE are thus warranted if private firms are not likely to prioritize these activities to a sufficient extent.

The theoretical rationale for public interventions in AE does not necessarily imply that those policy interventions are always effective and/or efficient. Indeed, public choice theory teaches us that governments and policies, just like markets, may fail as the outcome of a policy is contingent upon distributed agency among a collection of actors. To analyse the effectiveness and efficiency of AE initiatives we sketch a theoretical framework based on public choice theory and the concept of robustness in systems theory in the following section.

\subsection{Public choice, policy robustness and policy interventions}

While the research reviewed above gives some indications of the potential advantages related to $\mathrm{AE}$, the challenges associated with crafting such initiatives also need to be understood theoretically. Policies crafted to correct market failures may themselves be subject to limitations that at times make them costly and unproductive. Public choice theory is frequently used to make such assessments by taking the core economic notions of scarcity and rational self-maximizing behavior into the realm of policy (Mueller 2003). Classical economics posits that resources are scarce and as a consequence, individuals always face an opportunity cost in their allocation of resources. Thus, there is always a trade-off between the pursuit of one initiative in comparison to a different one. A central issue surrounding the effectiveness of policy initiatives is therefore the relative deadweight- and displacement effects. Deadweight effects mean that these initiatives may only be partially effective since some people would have engaged in the behaviour (e.g. academics starting a new firm) even without those initiatives. Displacement effects are the likelihood that policy initiatives aimed to encourage AE may generate negative spillovers by displacing current or new ventures being started without such support. Public choice theory also assumes that individuals are rational and seek to maximize their own utility. Public decision-making is therefore viewed as a negotiation between actors who may have diverging incentives but all seek to maximize their own utility (Downs 1957).

The presence of goal conflicts and incentives that point in different directions is a vital element of public choice theory (Tullock 1989). As policies affect actors in different ways, 
vested interest groups may influence e.g. legislation in a way that adversely affects the overall outcome of a new policy and hence the outcome is negatively affected. Generally speaking, the presence of goal conflicts implies that the outcome becomes less predictable and a policy initiative aimed to generate more AE may not result in the intended consequences.

As innovation processes are generally associated with uncertainty along both market and technology dimensions (Hoppe and Ozdenoren 2005; Macho-Stadler et al. 2007), it is difficult to know what mechanisms best cater to this process. In the specific case of AE, contextual factors might play an important role in determining the outcome of a particular initiative (Henrekson and Rosenberg 2001). These include e.g. national institutions, characteristics of the regional economy and properties of the concerned university. In order to assess the robustness of AE initiatives, contextual factors also need to be identified and a critical review needs to assess how likely they are to be fulfilled in various settings.

The boundary conditions derived above from public choice theory can be used to assess the overall robustness of AE initiatives. Robustness is an increasingly prevalent concept used to assess policies and the public choice assumptions of distributed agency and selfmaximizing behavior among concerned actors are important parameters when assessing the robustness of a social system (Pennington 2011). The notion of robustness originates in systems theory and refers to how well certain systems cope with stress and complexity. It has received increased attention within both the natural and the social sciences, including areas such as computing, biology, ecology and finance (Bonabeau et al. 1996; Doyle et al. 2003).

A robust system is capable of coping with uncertainties and significant variation in conditions without having its outcome adversely affected. Conversely, a system that lacks robustness experiences a sharp decline in performance when exposed to varying conditions. In the current framework, 'policy robustness' refers to how well AE functions under conditions of divergent incentives, conflicting goals and the potentially opportunistic behavior of actors involved (e.g. Bergek and Norrman 2008; Wennberg et al. 2011). While policies are often enacted to work under assumptions of optimal conditions (Pennington 2011) — such as in a well-functioning market or political system without corruption-most $\mathrm{AE}$ initiatives are implemented under varying conditions and it is therefore vital to (1) assess the likelihood that these conditions are met and (2) how the system will perform when they are not fulfilled. If the success of $\mathrm{AE}$ initiatives is contingent on many and/or very specific contextual factors and the overall system is riddled with diverging incentives, goal conflicts and tradeoffs, such initiatives cannot be regarded as robust as they are vulnerable to changes and imperfections.

A robust policy system thus means that the system is able to function well under varying conditions. Policy robustness is important in our analysis since it provides an umbrella framework to guide theorizing on the boundary conditions of successful AE initiatives and the outcome of these initiatives. A properly crafted policy should thus be designed in a way that makes its functionality robust against varying conditions (Leeson and Subrick 2006; Pennington 2011).

In sum, policy initiatives aimed at $\mathrm{AE}$ need to be assessed with regard to their robustness, i.e. their ability to cope with various input imperfections and complexity. These imperfections can be broadly understood in terms of incentives, goals conflicts, trade-offs and contextual factors. If $\mathrm{AE}$ initiatives are likely to succeed despite imperfections, they can be regarded as robust. If success is contingent on a large set of parameters unlikely to be fulfilled, such initiatives cannot be regarded as robust and such findings would raise questions with regarded to currently enacted policies, both on a national level and by 
universities. Our critical review of literature on AE thus seeks to assess how robust these initiatives are, thereby discussing their general effectiveness.

\section{Literature review methodology}

In order to perform a critical overview of the core empirical literature on AE initiatives we used a combination of snowball and search string sampling of articles. Our aim was to assess the robustness of $\mathrm{AE}$ initiatives and not merely to review and taxonomize it, given earlier contributions in this vein (Link et al. 2014). Since literature on AE is inherently interdisciplinary (Rothaermel et al. 2007) and has become quite extensive (Wright 2014) our analysis focused primarily on published and relatively well-cited articles. We thus used a snowball sample based on: (a) papers included in earlier literature reviews; (b) special issues on $\mathrm{AE}$ and related concepts; and (c) a word string search of articles with 50 or more citations. $^{1}$

As a first stage of the sampling a number of recent literature reviews on AE initiatives (including TTOs and USOs) were reviewed (Djokovic and Souitaris 2008; Grimaldi et al. 2011; Mian et al. 2016; O'Shea et al. 2008; Rothaermel et al. 2007; Siegel et al. 2007) as well as recent books (Feldman et al. 2002; Link et al. 2014; Shane 2004b; Wright et al. 2007). This resulted in 54 articles.

At the second stage of the sampling, special issues connected with Technology Transfer (TT) and academic entrepreneurship in these journals were searched for relevant contributions during the period 2000-2014. This yielded 48 additional articles, summing to 102 articles included in earlier literature reviews and cited in special issue of AE. In order to ascertain the comprehensiveness of our sample and make sure that no important contributions are missed, an additional string search of well-cited articles was conducted. We did this by searching for published articles including the terms "academic entrepreneurship", "academic entrepreneurship", "academic spin*”, "university entrepreneurship" or "university spin*" in Web of Science, Google Scholar and EBSCOhost. We also asked senior scholars in the field, including reviewers of the paper, about papers relevant to our selection. In this way 74 more articles not already included were added to the final sample.

The final 176 articles were organised into a spreadsheet containing information on the journal and year of publication, the type of article (empirical or theoretical) as well as information on data, main findings, and potential policy recommendations. About threefourths of the collected literature comes from the following journals: Research Policy, Journal of Technology Transfer, Small Business Economics, Technovation, Journal of Business Venturing and Management Science, consistent with Rothaermel et al. (2007).

The selected articles were read in detail and coded by two researchers independently of each other. First, the main actors involved in the process of AE are defined (faculty inventor, university, TTO, USO, investor, government agency, etc.). Second, a careful coding of arguments/results related to the effectiveness of AE was done. Since establishing intercoder reliability by presenting predetermined text segments risks altering meanings by lifting text from its original context or making unwarranted interpretations about the length of codable text, we followed Kurasaki's (2000) procedure to develop and assess intercoder

\footnotetext{
1 Since the field of academic entrepreneurship includes a variety of subfields and related concepts it is difficult to speak about the uniform use of terms, which is one more reason why the key word search was abandoned as the primary way of collecting the literature. The citation cut-off was conducted in December 2014.
} 
reliability with free-flowing text data for which the coders themselves determined the length of codable text segments. By doing so, we reached an intercoder reliability of $83 \%$, within the boundaries of exploratory research (Armstrong et al. 1997). Overlapping/ missing codes were identified and discussed until an agreed-upon coding scheme was finalized.

The results from our coding are divided into two groups-those that identify benefits and give support to $\mathrm{AE}$ initiatives and those that point to various challenges by highlighting different kind of problems and challenges with this way of spreading and commercialising knowledge. As example of benefits from AE, Anselin et al. (1997) showed that the spatial range of interaction between private $R \& D$ and university research extends longer than previously argued. As an example of challenges connected with AE, Clarysse et al. (2011a) highlights that universities' entrepreneurial capacity depends on attracting the right type of scientist with entrepreneurial capabilities. Articles without clear arguments about whether AE initiatives mainly come with benefits or face challenges were coded as neutral.

As a third stage of coding, the concepts connected with policy robustness identified in the theory part were searched for in the articles. We used both a content-based search for key words in the text corpus of the articles, as well as detailed reading by three of the authors individually to determine (a) incentives (coded as ' $\mathrm{I}$ ' in supplementary of Appendix 1) for individuals and organisations related to AE initiatives, (b) goal conflict in academic entrepreneurship initiatives (coded as ' $\mathrm{CG}$ ') identified in the paper, (c) potential trade-offs (coded as 'TO') between policy interventions seeking to foster AE and (d) the importance of contextual factors (coded as 'CX'). 24 articles did not receive any thirdstage codes.

After reading and coding all 176 articles by two researcher independently, ten articles were discarded since they served as introductions to special issues (five articles), did not cover our core theoretical concepts (one article) or did not include any words or concept corresponding to our second- and third-stage codes (four articles). The final sample of articles included in the analysis thus consists of 166 articles, summarized in supplementary of Appendix 1. The review was initiated in June, 2014, followed the sequence described above and the sample was finalized after the first revision of the article in September 2015.

\section{Analysis of the literature}

We start with some general observations from our review and then proceed to a more detailed analysis. Similar to earlier reviews, we find that the vast majority of the AE literature is empirical (138 articles, 82\%) and focus on testing a number of concepts concerning creation, development and productivity of USOs, incubators, TTOs or factors characterising scientists that tend to become inventors (see Table 1). We find that $49 \%$ of all studies in the sample indicated challenges concerning the effectiveness of AE, $11 \%$ pointed at benefits related to the phenomenon and $40 \%$ can be regarded as neutral (see Table 1 below). These figures suggest a cause for concern regarding the effectiveness of academic entrepreneurship, highlighting the importance of our objective: to deepen the analysis and discussion about the generality of AE initiatives and assess the robustness of these.

Concerning the presence of our theoretical concepts, we find that almost one-third $(28 \%)$ of the studies analysed state that there are significant conflicting goals inside these 
Table 1 Summary of the results from coding

\begin{tabular}{lc}
\hline Concepts & Percent of articles (\%) \\
\hline Effectiveness of academic entrepreneurship (code) \\
Benefits & 11 \\
Challenges & 49 \\
Neutral & 40 \\
Incentives (I) & 32 \\
Goal conflict (CG) & 29 \\
Tradeoffs (TO) & 8 \\
Contextual factors (CX) & 52 \\
\hline
\end{tabular}

organisations, or between individuals and organisations. About half of the studies indicate strong context dependency in how AE functions. These observations suggest that a number of boundary conditions affecting - or even determining - the outcome of AE initiatives have been identified in the research to date. In the following sections we proceed to analyse these boundary conditions in more detail. Here, we see boundary conditions as lower and upper limits to when policies are effective (Franzese 2002). The importance of boundary conditions has received increasing attention in the innovation literature (e.g. Kaufmann and Tödtling 2001). For example, Murmann and Frenken (2006) explain how boundary conditions (such as low heterogeneity of customer tastes and high complexity of the production process) affect the predictive value and scope of dominant design theory. A focus on boundary conditions means that we are not only identifying critical factors, but also ask at what levels those factors must be set in order for $\mathrm{AE}$ initiative to yield the desired results.

\subsection{Incentives and motives for engaging in academic entrepreneurship}

Academic entrepreneurs and the factors that determine the propensity for faculty to engage in entrepreneurship is a salient topic in the literature (Clarysse et al. 2011a) and also apparent in our review. A recurring topic in our review concerns incentive structures related to faculty's academic entrepreneurs (54 articles, representing $32 \%$ of studies analysed). Financial incentives, often in the form of higher royalty shares, seem to have a positive effect on entrepreneurial activity (Friedman and Silberman 2003; Lach and Schankerman 2004; Link and Siegel 2005; Link et al. 2011; Rogers et al. 2000) and the continued revenues from commercialised research is seen as a necessary condition for future success and productivity among academic entrepreneurs. Several studies highlight the lack of adequate incentive structures in AE policies and systems (e.g. Clarysse et al. 2007; Debackere and Veugelers 2005; Franklin et al. 2001; Laukkanen 2003; Rasmussen and Borch 2010; Siegel et al. 2007). With few and uncertain advantages to personal wealth and research career of becoming an entrepreneur, most academics seem to prefer keeping a 'safe position' at the university (Rasmussen and Borch 2010, p. 607, see also Gurdon and Samsom 2010).

Another form of private incentive is related to the trade-off between the time a scientist can devote to commercialization activities and time he/she could dedicate to new research. If academics engage in entrepreneurship but continue to prioritize their research (Jain et al. 2009) this may decrease the productivity of the firms they are involved in (Toole and Czarnitzki 2009). At the same time, some concerns have been raised regarding the fact that 
commercialisation activities may lead to academic brain drain and negatively affect knowledge production in the not-for-profit research sector (Toole and Czarnitzki 2010). Klofsten and Jones-Evans (2000) suggest that contract research is a mechanism that allows for the commercialization of academic research without such brain drain. At the same time, most academics engage with industry not primarily to pursue commercialization but to further their research agenda (D'Este and Perkmann 2011; Wright et al. 2014). Contract research thus represents an alternative commercialization mechanism compared to e.g. academics' involvement in USOs. As Wright et al. (2008) note, this is however not reflected in most policies since contract research is rarely included in the incentive structure of the universities.

We also observe in the review that certain 'entrepreneurial qualities' that an academic possesses are often identified as having a strong influence on his/her chances of successfully taking part in commercialisation activities. A number of papers in supplementary of Appendix 1 argues that the academics involved in entrepreneurial activities tend to be those with high productivity and an ability to identify opportunities to link research and commercialisation (Haeussler and Colyvas 2011; Landry et al. 2006; Vohora et al. 2004) and academics might use ventures as an "extended research lab" (Etzkowitz 2003).

Another central aspect of such entrepreneurial qualities seems to be related to academics' social capital or network. For example, Aldridge and Audretsch (2011) highlight the social capital of academics as a central determinant of their likelihood of being involved in knowledge commercialization. Similarly, Haeussler and Colyvas (2011, p. 41) argue that "the productivity of scientists to engage in TT is conditioned by their positions in the social structure of science and outlooks on their careers". At the same time, it has been shown that academics frequently lack this important social capital and that they have structural holes in their networks which hamper commercialization (Mosey and Wright 2007).

Even in studies which are not directly concerned with the traits of academics highlight the fact that many researchers are not willing to master skills necessary for commercialisation, and thus are not suitable to become entrepreneurs (Klofsten and Jones-Evans 2000; Vohora et al. 2004). A comparative study of USOs and corporate spin-offs by Wennberg et al. (2011) found that industrial experience of scientists, though seldom possessed, is crucial for the success of USOs. Further, the employment of external actors such as 'surrogate entrepreneurs' from industry to work with researchers has been highlighted as potentially more beneficial (Franklin et al. 2001; Lundqvist 2014; Lockett et al. 2003). Our review hence suggests that successful academic entrepreneurs seem to exhibit a set of distinguishing traits compared to the overall population of academics. Universities may be capable of creating ambidextrous structures that encourage both research and commercialization, but this ambidexterity is rarely found among research staff (Ambos et al. 2008). This begs the question whether these characteristics are present in most of the settings where AE initiatives are enacted. For example, when researchers do not posit necessary commercialization skills or networks and/or are not willing to develop them, boundary conditions for successful AE are arguably not met. In this case an AE initiative may result in the creation of a new venture, but not the anticipated growth and success. From a public choice perspective, policies that seek to promote successful scientists to commercialize their findings without ensuring that these also have the necessary entrepreneurial skillset are therefore not robust. 


\subsection{Goals of academic entrepreneurship initiatives}

48 papers in our review (29\%) noted the existence of goal conflicts, for example, between public officials and universities, academics and private investors, or academics and their faculties (Bergek and Norrman 2008; Yu and Nijkamp 2009). This is a vital observation, given that an important part of the robustness concept is related to the fact that actors may have diverging goals and preferences. If we assume actors to be rational-as most policy initiatives do-AE initiatives would arguably perform well if individual goals are aligned with the overall objective. If this is not the case, the outcome is likely to be different from the intended one, thus implying a lack of robustness (Buchanan and Tullock 1962).

A few papers in our review mention different possibilities for conflicts of interests at universities with regard to the process of TT because a lot of emphasis still lies on academic careers, publications and the traditional tasks of teaching and researching in comparison to governments' goals of higher pace of innovation and economic growth (e.g. Franklin et al. 2001; Kenney and Patton 2011; Mustar et al. 2006; Pirnay et al. 2003; Rasmussen et al. 2011). Indeed, several articles in our literature review highlights the fact that university faculty frequently perceives such internal goal conflicts and struggles to coordinate all initiatives (Jain et al. 2009; Laukkanen 2003; Thursby and Thursby 2011; Rasmussen et al. 2006). Also university managers may have conflicting goals when compared to other actors in the commercialization process such as private investors. For example, Clarysse et al. (2007) point out that university managers who receive public funds for developing many USOs seldom have incentives to develop the USOs further. This indicates a risk that publicly sponsored USO policies generate large numbers of rather unproductive firms, rather than the growing firms motivating such policies. Some scholars suggest that TTO may at times be unproductive for technology transfer due to misaligned incentives and lack of capabilities (Kenney and Patton 2009). Our review also includes studies dealing with university incubators, noting that these often have goals that are vague or incongruent, impeding their productivity (Amezcua 2010; Clarysse et al. 2005). Evaluation of incubators aimed at assessing their productivity can also be problematic as the subjectivity and perceptions of public officials create problems for carrying out evaluations (Yu and Nijkamp 2009).

Goal conflicts between venture capital and USOs or TTOs constitute another potential obstacle for the development of AE initiatives. These types of goal conflicts include different views on the length and time of commercialisation or issues around intellectual property rights (Bramwell and Wolfe 2008). Moreover, investors usually have difficulties assessing the quality of technology while researchers cannot always predict the real market value of their innovations (Macho-Stadler et al. 2007). Therefore, venture capitalists are often less likely to invest in the starting phase of the USO being afraid of free-riding and risks of the unknown market (Takalo and Tanayama 2010; Wright et al. 2006).

In sum, goal congruence between various $\mathrm{AE}$ stakeholders is an important boundary condition for successful AE initiative, influencing the overall effectiveness of these systems. When successful AE relies upon connecting a number of parties, diverging goals may be detrimental and $\mathrm{AE}$ initiatives directed towards a system that relies on coordination between different actors will not be robust and effective. Our review points at several such goal conflicts which are likely to impede $\mathrm{AE}$ initiatives. 


\subsection{Policy trade-offs in academic entrepreneurship}

In our sample of 166 papers, the issue of trade-offs was mentioned in 13 cases (8\%). To start with, a government supporting AE with rich subsidies should be aware of possible crowd-out effects of small local firms (Audretsch et al. 2012) and crowding out of the public goods nature of science as academics are less prone to disclose their inventions before patens recognition (Colyvas and Powell 2007).

Trade-offs can also be connected to the choice that a university should make while striking a balance between education and commercialisation (Wennberg et al. 2011) and the most effective combination of resources and capabilities for generating USOs. A study of high technology university start-ups by Ensley and Hmieleski (2005) showed that universities often direct resources to technology development and marketing but less resources for developing the management teams commonly seen by investors as necessary for firm success.

Trade-offs can be connected to even more specific issues such as TTO strategies (Markman et al. 2005) or the choices between an academic career and entrepreneurship that individual scientists may have to make (Toole and Czarnitzki 2010). Incubator strategies can also be an issue of trade-offs: closer ties to the university imply higher quality research but also increases the risk of the company remaining in the incubator instead of becoming independent (Rothaermel and Thursby 2005a; Johansson et al. 2005).

In sum, our review identifies several policy trade-offs within AE systems. The combined effects of those conflicts are likely to affect the outcome of these initiatives. From a public choice perspective, a critical boundary condition for policy success is consistency of the policy measure (Sabatier 1986). Robust AE initiatives need to be both internally and externally consistent. When internally inconsistent policies are deployed, gains are fully or partly offset by losses elsewhere as the policy incentivises conflicting behaviour. For example, consider a university that by default takes relatively large equity stakes in USOs. Although the university may be able to sell those shares to the benefit of the university at large, the policy may disincentivise private investors as the founding team is less aligned with the success of the USO. When growth is dependent upon external financing, the university then forsake a large win from a small stake in order to gain small win from a large stake. Similarly, when externally inconsistent policies are deployed, one AE initiative may be at odds with another. As complete goal congruence is not possible, some trade-offs are inevitable. Yet, inconsistent AE initiatives mean that the net societal result of such policies may rapidly approach zero or even become negative due to distortion effects (Dahlman 1979). Well-functioning AE initiatives require that several different actors such as researchers, incubators, university officials and venture capitalists are aligned (Mian et al. 2016). Our literature review indicates that these actors often differ both in terms of incentives and competencies, and thus the overall system may not generate the intended outcomes.

\subsection{The role of contextual factors}

As stated in the theoretical framework, contextual factors are related to institutions and legislation, local and regional economic characteristics and university specific traits. If the success of $\mathrm{AE}$ is highly dependent on a set of contextual criteria that are rare and unlikely to be fulfilled, these initiatives cannot be regarded as robust. 
From our reading and analysis of the sample of 166 studies, we find that the contextual nature of $\mathrm{AE}$ is portrayed in 87 articles (52\%). Context dependency here can be seen in a very broad sense including characteristics of the legislature and national institutions (Braunerhjelm 2007; Mowery and Sampat 2005), local and regional environment (Colombo and Delmastro 2002; Lerner 1999; Stephan 2013), specific characteristics and resources of universities (Bonaccorsi et al. 2014; Link and Siegel 2005), TTOs (Clarysse et al. 2011a; Lockett and Wright 2005), as well as the social environment within and across academic departments (Bercovitz and Feldman 2008; Stuart and Ding 2006; Toole and Czarnitzki 2009) and access to financial markets (Carayannis et al. 1998).

\subsubsection{Institutional and legislative context}

While few studies in our sample cover variance in institutional and legislative context, it is highlighted in several articles that the American examples of AE like MIT and Silicon Valley have become role models for the rest of the world (Braunerhjelm 2007; Miner et al. 2012) but as Mowery and Sampat (2005) argue, AE in the USA and its unique education system have evolved over decades and were not just triggered by the adoption of the BayhDole Act (see also Henrekson and Goldfarb 2003). The same path of TT should therefore be followed with caution and regard to local specificities.

\subsubsection{Regional and local context}

Universities located in economically stronger regions with access to venture capital have been shown to boost USOs productivity and success (Audretsch et al. 2012; Chapple et al. 2005). Fini et al. (2011) claim that characteristics of industries present in the region and the existence of companies with a similar profile can also play a considerable role. Even the sometimes criticised study by Lerner (1999) that shows positive performance of USOs that got support and findings from the Small Business Innovation Research (SBIR) programme, indicate that this performance depends to a great extent on location in regions with considerable venture capital activity. Comparing incubators in Sweden and Finland, Autio and Klofsten (1998) also point out that the main differences between the two depend on variations in the local industrial base and institutional settings. Thus, local and contextdependent support mechanisms, including subsidies and entrepreneurial support services seem to in general exhibit a strong influence on USOs success. Universities thus face a strong need to adjust policies around TT to the local conditions and tailor best practice models in accordance with existing skills and experience (Bergek and Norrman 2008; Miner et al. 2012), which makes the universality of TTO initiatives difficult to identify.

\subsubsection{University context}

Thirty-one articles in our review mention various aspects of the university context, covering: the milieu that the university provides for academics and USO activities; resources and professional capabilities; university policies, and social norms on faculty. As for the context related to resource base and the type of university, it seems that large and highly competitive universities with developed infrastructure (e.g. Bonaccorsi et al. 2014 Landry et al. 2006; Link and Siegel 2005), traditions of starting new firms and entrepreneurial environments (Bercovitz and Feldman 2008; O’Shea et al. 2005; Thursby and Kemp 2002) experience success concerning TT and spinning-off new enterprises. 
The papers on TTOs in our review highlights some critical contextual factors for the success of TT, specifically, the existence professional capabilities of the universities needed to launch and support USOs (Vohora et al. 2004) as well as a sizeable number of staff for technology licensing (Rogers et al. 2000). Also staff and employment systems in universities have been identified to affect USO formation, specifically the scientific quality of faculty, their size, and enumeration (O'Shea et al. 2005; Rogers et al. 2000; Thursby and Kemp 2002). Social norms among faculty, including networks and attitudes of colleagues, also seem to play an important role in AE (Bercovitz and Feldman 2008; Stuart and Ding 2006), for example by affecting the career paths that academics consider (Haeussler and Colyvas 2011).

\subsubsection{TTO and its capabilities}

TTO is an important vehicle for commercialization of university knowledge. Its configuration and activities affect to a great extent the chances of success when it concerns $\mathrm{AE}$ (Huyghe et al. 2013; Macho-Stadler et al. 2007). However, the existence of TTOs may play only a marginal role in inspiring academics to commercialize their knowledge since only a small share of TTO activities concern the development of stimulating social environments and entrepreneurship training (Clarysse et al. 2011b).

A final contextual factor for TT success identified in our review concerns the capabilities of TTO staff (Debackere and Veugelers 2005; Lockett and Wright 2005; Powers and McDougall 2005). Specifically, TTO experience in terms of age (Carlsson and Fridh 2002) and size of its staff (Foltz et al. 2000) have been suggested to be positively related to TTO performance when measured as number of new ventures, royalty income, or number of patents commercialized (Carlsson and Fridh 2002). However, the study by Chapple et al. (2005) found TTOs to have low levels of absolute efficiency and that skill development was needed in order to reap any benefits from these structures. The same researchers also found that older TTOs seem to be less efficient, suggesting an absence of learning effects, or even negative learning. Moreover, the complexity of the entrepreneurial environment and the number of possible choices and strategies can often lead to the failure of TTOs (Hoppe and Ozdenoren 2005). While effective AE initiatives may rely on TTOs, the critical boundary condition is not the presence of a TTO per se but the degree to which the TTO complements the researcher in some crucial dimension. For example, a number of studies (e.g. Colombo and Piva 2012; Ensley and Hmieleski 2005; Fini and Toschi 2016) underscore the particular resources endowed and not endowed in academic start-ups versus non-academic start-ups, suggesting TTOs competencies must complement those specific needs. In other words, the exact value of this boundary condition will depend on the needs of the researcher and will differ from university to university.

Summarizing the above, our review clearly shows contextual factors play an important role in determining the success of AE initiatives. Published studies from North America and Europe predominate, with studies on AE initiatives in Asia, South America and Africa constitute an important research gap. In those settings where institutional, regional, university and TTO contexts fulfil the above identified success factors, we can expect AE initiatives to result in positive knowledge spillovers and in the long term, economic growth. Our review of research on the topic indicates that these initiatives are riddled with goal conflicts and impose high demands on the university and researchers involved. These boundary conditions seem unlikely to be fulfilled in many and perhaps not even most of the settings where universities and governments are enacting AE initiatives (Kaufmann and Tödtling 2001). While these activities may in some cases result in both innovation and 
growth, the overall idea that universities should prioritize entrepreneurship on par with research and education does not meet the robustness criteria. These findings imply that policy makers need to be cautious when importing and implementing policies based upon best practice from other settings.

\subsection{Robust and effective academic entrepreneurship initiatives}

Our review of the literature in the above suggests a few central factors as highly salient for determining the robustness of $\mathrm{AE}$ initiatives. Based on these central factors we outline below a suggested conceptual model of robust and effective AE initiatives based on the notion of alignment (Gottschalg and Zollo 2007). The model (Fig. 1 below) depicts one antecedent (Activating AE) and two enabling factors to successful commercialization (Aligning capabilities, Aligning interests). AE initiatives are generally directed towards increasing the number of academics involved in $\mathrm{AE}$, with limited attention paid to whether the policy materializes into successful commercialization, i.e. profitable and growing ventures. Our review discusses a number of boundary conditions for successful commercialization, in particular incentives, goals conflicts, trade-offs and contextual factors. Consistently the review reminds us that these boundary conditions are seldom met-and as a result most $\mathrm{AE}$ initiatives cannot be considered robust and effective. To be successful AE initiatives must not only activate $\mathrm{AE}$ but also align the capabilities and interests of key stakeholders. In other words, there is no direct relationship between activating AE and successful commercialization, but the relationship is moderated by how well the interests and capabilities of key stakeholders (e.g. academic inventors, lab managers, TTO etc.) are aligned with the goal of the AE initiative. A successful AE initiative must either have the ability to influence alignment or be adapted to match with the capabilities and interests of universities, TTOs and academics. Needless to say, the latter means adjusting the goal of the AE initiatives as well.

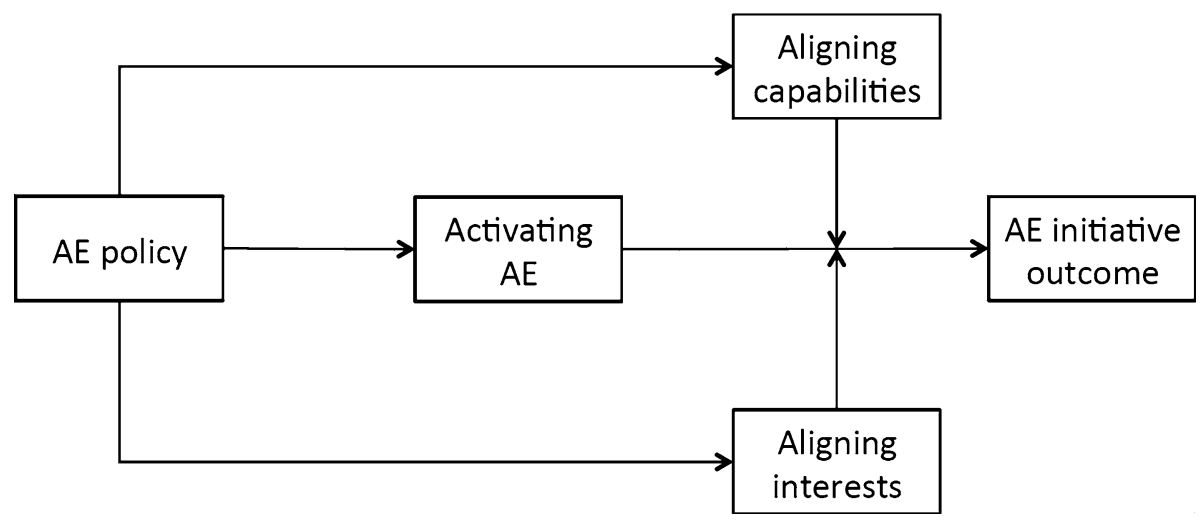

Fig. 1 Suggested conceptual model for robust AE initiatives 


\section{Discussion}

Drawing upon public choice theory we provided a critical review on the efficiency and effectiveness of AE. The review focused on the robustness of AE initiatives. The term robustness refers to a system's ability to cope with stress and imperfections. If a system only performs well when certain specific criteria are fulfilled (boundary conditions) but delivers worse results under less optimal circumstances, it cannot be regarded as robust. Our review provides several implications, both for research and practice.

First, the review confirmed the expectation that successful AE is contingent upon a number of factors such as individual incentives and capabilities, the goals of and trade-offs between different actors as well as a set of different contextual factors: $49 \%$ of articles reviewed pointed at challenges or boundary conditions that impose limitations on the outcome of AE initiatives, $29 \%$ identify conflicting goals both inside and between organizations devoted to these efforts, $47 \%$ of the sample points at strong context dependence. Taken together, several articles suggest that academics are unlikely to posit any comparative advantage in entrepreneurship. These findings suggest that variation in AE success is dependent upon a greater number of factors than generally considered. Our review thus reminds us that omitted variables and selection biases are deadly to good theorizing and policy conclusions (Colombo and Piva 2012; Ensley and Hmieleski 2005; Fini and Toschi 2016). It also reminds us to continue the pursuit of comparative research on AE initiatives (e.g. Klofsten and Jones-Evans 2000).

Second, the review points to a lack of robustness of AE initiatives. Although there is ample empirical support for the claim that AE can be a successful strategy for technology transfer, the outcome of $\mathrm{AE}$ is contingent upon a set of conditions that do not necessarily hold when initiatives are enacted. Indeed, the findings suggest that the outcome of $\mathrm{AE}$ initiatives may in most settings be less positive than expected, as AE seem to depend on a host of criteria that are unlikely to be fulfilled in many cases. In order to assess academic entrepreneurship initiatives, the relative deadweight effects and displacement effects also need to be taken into consideration. Deadweight effects mean that policies may only be partially effective since some people would have engaged in the behaviour (e.g. academics starting a new venture) even without the policy initiatives. Displacement effects are the likelihood that policy initiatives aimed to encourage AE—such as incubators, subsidies or targeted support-may generate negative spillovers by displacing current or new ventures being started without such support. Our review indicates that among the many studies seeking to evaluate the effectiveness of AE initiatives, still relatively few studies have taken such factors into account (important exceptions include: Colombo and Delmastro 2002; Colombo and Piva 2012; Ensley and Hmieleski 2005; Fini and Toschi 2016; Rannikko and Autio 2015). Arguably, a thorough investigation of relative deadweight and displacement effects would imply further caution with regard to the implementation of academic entrepreneurship initiatives. As a result, the review calls for caution when policymakers try to replicate successful AE initiatives in environments where critical conditions are not met. Policies may not be easily transferred, as their success is contingent upon legal and institutional factors, regional characteristics as well as the entrepreneurial capabilities of a particular university. We contribute by highlighting 'robustness' as a key quality criterion of any AE initiatives. A robust policy then likely consists of a set of actions directed towards a goal, rather than one isolated action believed to achieve the same goal. Robust policies need to cope with e.g. divergent incentives, conflicting goals and opportunistic behaviour (e.g. Bergek and Norrman 2008). To that understanding we 
add that robust policies are designed in such a way that boundary conditions are taken into account in each specific application of AE.

Abstracting from these observations we develop a model that highlights the ability to align capabilities and interests of various stakeholders for AE initiatives to materialize into successful commercialization. First, the model suggests that AE initiatives should activate entrepreneurial behavior among its intended target groups. Prior research has investigated this mechanism at length as evident in our review. Second, the model suggests that for academic entrepreneurship to be successful the AE initiative must also ensure that the necessary capabilities and motivation is in place. Here, we draw on the concept of alignment (Gottschalg and Zollo 2007) to capture the correspondence between individual, organizational and policy-level aspiration (aligning interests) and potential (aligning capabilities) to succeed. Organizational scholars are painfully aware of the challenges to get individuals to behave according goals set by others (Alchian and Demsetz 1972; Jensen and Meckling 1976). For AE initiatives to actually lead to successful outcomes, key members of the university must be motivated to behave according to the goals of the policy. As illustrated in our review, many academics are not necessarily willing to pursue commercialization at the expense of abandoning research. Similarly, academics, TTOs and other partners must possess the necessary entrepreneurial capabilities. And these capabilities must be aligned with the goal of the policy. The model reveals a number of challenges to policy-makers and university management. First and foremost that individual preferences differ and matter-not all potential academic entrepreneurs will (and should) react similarly to a given AE initiative. However, to be robust the policy cannot only be directed towards activating dormant and believed-to-be academic entrepreneurs. Policymakers must understand (and university management must remind themselves) that academics are not only incentivized by $\mathrm{AE}$ initiatives - other policies directed towards teaching and research are likely as-if not more-important in shaping behavior. When aligning capabilities universities (in practice often the TTO) must critically ask whether necessary competences should be developed in-house or acquired through partnerships. Consistent with public choice theory, decisions to align capabilities and interests must always consider the opportunity cost of doing so. Strong incentives to draw successful academics away from research and teaching may not necessarily be the best overall strategy, and we discuss alternatives below. Only when alternatives and opportunity costs are considered can AE initiatives be considered robust.

Third, the aggregated results from studies in our literature review suggest that alternative channels_-such as licensing, contract research, 'pure' knowledge spillovers and increased labor mobility (Audretsch and Keilbach 2005) — might be better at transforming university research into goods and services. As highlighted by Wright et al. 2014, corporate-sponsored research can be surpris-ingly valuable for further innovation, and are licensed and cited more often than public sponsored research. Scholars, policymakers and practitioners should remember that $\mathrm{AE}$ is one among many means of transferring knowledge from universities. Knowledge transfer might be more effectively facilitated by researchers who engage in such activities rather than by creating entrepreneurial ventures (Klofsten and Jones-Evans 2000). Student ventures have been noted to increase in number (Bolzani et al. 2014) and often outperform firms started by researchers (Åstebro et al. 2012). This highlights the crucial role of universities in education, which in time may in fact generate more and better entrepreneurship than the creation of USOs by faculty. The theoretically salient notion of knowledge spillovers and the fact that innovation is crucial for economic growth still point at universities having an important, and perhaps also expanded role in the economy (Arrow 1962; Salter and Martin 2001). But the means may 
vary from situation to situation. Establishing the boundary conditions for $\mathrm{AE}$ allows us to inform policymakers when to support $\mathrm{AE}$ and when not to. As we have seen AE holds great promise but is not a silver bullet. Rather, robust policymaking is about firing the right bullet in the right direction - and sometimes resort to less lethal modus operandi. Future research that seeks to address the overall robustness rather than specific components of $\mathrm{AE}$ systems are needed.

\section{Conclusion}

Our critical review suggests that crafting an innovation system around a university is associated with several constraints and challenges. The lack of robustness in these systems implies that it is difficult to emulate environments such as Route 121 in the Boston area or Silicon Valley as these contexts are highly specific. It also implies that other mechanisms of transferring knowledge from universites to the surrounding economy might in many cases be more advantageous.

Acknowledgements We are grateful for helpful comments from the editors and two anonymous referees, Niclas Berggren, Sven-Olov Daunfeldt, Magnus Henrekson, Nils Karlson, Magnus Klofsten, Einar Rasmussen, Mike Wright and seminar participations at Kristianstad University and the International Research Conference on Technology Business Incubation Mechanisms and Sustainable Regional Development at Toulouse Business School. Emilie Videnord provided excellent research assistance. Funding was provided by VINNOVA and the Swedish Research Council (340-2013-5460). All errors remain ours.

Open Access This article is distributed under the terms of the Creative Commons Attribution 4.0 International License (http://creativecommons.org/licenses/by/4.0/), which permits unrestricted use, distribution, and reproduction in any medium, provided you give appropriate credit to the original author(s) and the source, provide a link to the Creative Commons license, and indicate if changes were made.

\section{References}

Abramo, G., D’Angelo, C. A., Ferretti, M., \& Parmentola, A. (2012). An individual-level assessment of the relationship between spin-off activities and research performance in universities. $R \& D$ Management, 42(3), 225-242.

Acs, Z. J. (2002). Innovations and the growth of cities. Cheltenham: Edward Elgar.

Aerts, K., Matthyssens, P., \& Vandenbempt, K. (2007). Critical role and screening practices of European business incubators. Technovation, 27(5), 254-267.

Alchian, A. A., \& Demsetz, H. (1972). Production, information costs, and economic organization. The American Economic Review, 62, 777-795.

Aldridge, T. T., \& Audretsch, D. (2011). The Bayh-Dole act and scientist entrepreneurship. Research Policy, 40(8), 1058-1067.

Ambos, T. A., Mäkelä, K., Birkinshaw, J., \& D’Este, P. (2008). When does university knowledge get commercialized? Creating ambidexterity in research institutions. Journal of Management Studies, 45(8), 0022-2380.

Amezcua, A. S. (2010). Boon or boondoggle? Business incubation as entrepreneurship policy. Syracuse: Syracuse University.

Anselin, L., Varga, A., \& Acz, Z. (1997). Local geographic spillovers between university research and high technology innovations. Journal of Urban Economics, 42(3), 422-448.

Armstrong, D., Gosling, A., Weinman, J., \& Marteau, T. (1997). The place of inter-rater reliability in qualitative research: An empirical study. Sociology, 31(3), 597-606.

Arrow, K. J. (1962). The economic implications of learning by doing. Review of Economic Studies, 29(80), $155-173$.

Åstebro, T., Bazzazian, N., \& Braguinsky, S. (2012). Startups by recent university graduates and their faculty: Implications for university entrepreneurship policy. Research Policy, 41(4), 663-677. 
Audretsch, D. B., \& Feldman, M. P. (1996). R\&D spillovers and the geography of innovation and production. The American Economic Review, 86, 630-640.

Audretsch, D. B., Hülsbeck, M., \& Lehmann, E. E. (2012). Regional competitiveness, university spillovers, and entrepreneurial activity. Small Business Economics, 39(3), 587-601.

Audretsch, D. B., \& Keilbach, M. (2005). Entrepreneurship capital and regional growth. The Annals of Regional Science, 39, 457-469.

Audretsch, D. B., \& Lehmann, E. E. (2005). Does the knowledge spillover theory of entrepreneurship hold for regions? Research Policy, 34(8), 1191-1202.

Autio, E. (1997). New, technology-based firms in innovation networks symplectic and generative impacts. Research Policy, 26(3), 263-281.

Autio, E., \& Klofsten, M. (1998). A comparative study of two European business incubators. Journal of Small Business Management, 36(1), 30-43.

Autio, E., \& Yli-Renko, H. (1998). New, technology-based firms as agents of technological rejuvenation. Entrepreneurship and Regional Development, 10(1), 71-92.

Bathelt, H., Kogler, D. F., \& Munro, A. K. (2010). A knowledge-based typology of university spin-offs in the context of regional economic development. Technovation, 30(9-10), 519-531.

Becker, B., \& Gassmann, O. (2006). Corporate incubators: Industrial R\&D and what universities can learn from them. Journal of Technology Transfer, 31(4), 469-483.

Benneworth, P., \& Charles, D. (2005). University spin-off policies and economic development in less successful regions: Learning from two decades of policy practice. European Planning Studies, 13(4), 537-557.

Bercovitz, J., \& Feldman, M. (2008). Academic entrepreneurs: Organizational change at the individual level. Organization Science, 19(1), 69-89.

Bercovitz, J., Feldman, M., Feller, I., \& Burton, R. (2001). Organizational structure as a determinant of academic patent and licensing behavior: An exploratory study of Duke, Johns Hopkins, and Pennsylvania State Universities. Journal of Technology Transfer, 26(1-2), 21-35.

Bergek, A., \& Norrman, C. (2008). Incubator best practice: A framework. Technovation, 28(1), $20-28$.

Berggren, E., \& Dahlstrand, A. L. (2009). Creating an entrepreneurial region: Two waves of academic spinoffs from Halmstad University. European Planning Studies, 17(8), 1171-1189.

Bernasconi, A. (2005). University entrepreneurship in a developing country: The case of the P. Universidad Católica de Chile, 1985-2000. Higher Education, 50(2), 247-274.

Bjørnåli, E., \& Gulbrandsen, M. (2010). Exploring board formation and evolution of board composition in academic spin-offs. Journal of Technology Transfer, 35, 92-112.

Bolzani, D., Fini, R., Grimaldi, R., \& Sobrero, M. (2014). University spin-offs and their impact: Longitudinal evidence from Italy. Journal of Industrial and Business Economics, 41(4), 237-263.

Bonabeau, E., Theraulaz, G., \& Deneubourg, J.-L. (1996). Mathematical model of self-organizing hierarchies in animal societies. Bulletin of Mathematical Biology, 58(4), 661-717.

Bonaccorsi, A., Colombo, M. G., Guerini, M., \& Rossi-Lamastra, C. (2014). The impact of local and external university knowledge on the creation of knowledge-intensive firms: Evidence from the Italian case. Small Business Economics, 43, 1-27.

Bonardo, D., Paleari, S., \& Vismara, S. (2010). The M\&A dynamics of European science-based entrepreneurial firms. Journal of Technology Transfer, 35, 141-180.

Bonardo, D., Paleari, S., \& Vismara, S. (2011). Valuing university-based firms: The effects of academic affiliation on IPO performance. Entrepreneurship Theory and Practice, 35, 755-776.

Bramwell, A., \& Wolfe, D. A. (2008). Universities and regional economic development: The entrepreneurial University of Waterloo. Research Policy, 37(8), 1175-1187.

Braunerhjelm, P. (2007). Academic entrepreneurship: Social norms, university culture and policies. Science and Public Policy, 34(9), 619-631.

Broström, A., McKelvey, M., \& Sandström, C. (2009). Investing in localized relationships with universities: What are the benefits for R\&D subsidiaries of multinational enterprises? Industry and Innovation, 16(1), 59-78.

Bruneel, J., Ratinho, T., Clarysse, B., \& Groen, A. (2012). The evolution of business incubators: Comparing demand and supply of business incubation services across different incubator generations. Technovation, 32(2), 110-121.

Buchanan, J. M., \& Tullock, G. (1962). The calculus of consent (Vol. 3). Ann Arbor: University of Michigan Press.

Buenstorf, G. (2007). Evolution on the shoulders of giants: Entrepreneurship and firm survival in the German laser industry. Review of Industrial Organization, 30(3), 179-202.

Carayannis, E. G., Rogers, E. M., Kurihara, K., \& Allbritton, M. M. (1998). High-technology spinoffs from government R\&D laboratories and research universities. Technovation, 18(1), 1-11. 
Carlsson, B., \& Fridh, A.-C. (2002). Technology transfer in United States universities. Journal of Evolutionary Economics, 12(1-2), 199-232.

Chapple, W., Lockett, A., Siegel, D., \& Wright, M. (2005). Assessing the relative performance of UK university technology transfer offices: Parametric and non-parametric evidence. Research Policy, 34(3), 369-384.

Cheng, S., \& Schaeffer, P. V. (2011). Evaluation without Bias: A methodological perspective on performance measures for business incubators. Region et Developement, 33, 211-225.

Clarysse, B., \& Moray, N. (2004). A process study of entrepreneurial team formation: The case of a research-based spin-off. Journal of Business Venturing, 19(1), 55-79.

Clarysse, B., Tartari, V., \& Salter, A. (2011a). The impact of entrepreneurial capacity, experience and organizational support on academic entrepreneurship. Research Policy, 40(8), 1084-1093.

Clarysse, B., Wright, M., Lockett, A., Mustar, P., \& Knockaert, M. (2007). Academic spin-offs, formal technology transfer and capital raising. Industrial and Corporate Change, 16(4), 609-640.

Clarysse, B., Wright, M., Lockett, A., Van de Velde, E., \& Vohora, A. (2005). Spinning out new ventures: A typology of incubation strategies from European research institutions. Journal of Business Venturing, 20(2), 183-216.

Clarysse, B., Wright, M., \& Van de Velde, E. (2011b). Entrepreneurial origin, technological knowledge, and the growth of spin-off companies. Journal of Management Studies, 48(6), 1421-1442.

Cohen, W. M., Nelson, R. R., \& Walsh, J. P. (2002). Links and impacts: The influence of public research on industrial R\&D. Management Science, 48(1), 1-23.

Colombo, M. G., D'Adda, D., \& Piva, E. (2010). The contribution of university research to the growth of academic start-ups: An empirical analysis. Journal of Technology Transfer, 35(1), 113-140.

Colombo, M. G., \& Delmastro, M. (2002). How effective are technology incubators? Evidence from Italy. Research Policy, 31(7), 1103-1122.

Colombo, M. G., \& Piva, E. (2012). Firms' genetic characteristics and competence-enlarging strategies: A comparison between academic and non-academic high-tech start-ups. Research Policy, 41(1), 79-92.

Colyvas, J., Crow, M., Gelijns, A., Mazzoleni, R., Nelson, R. R., Rosenberg, N., et al. (2002). How do university inventions get into practice? Management Science, 48(1), 61-72.

Colyvas, J. A., \& Powell, W. W. (2007). From vulnerable to venerated: The institutionalization of academic entrepreneurship in the life sciences. Research in the Sociology of Organizations, 25, 219-259.

Cosh, A., \& Hughes, A. (2010). Never mind the quality feel the width: University-industry links and government financial support for innovation in small high-technology businesses in the UK and the USA. Journal of Technology Transfer, 35(1), 66-91.

Czarnitzki, D., Rammer, C., \& Toole, A. A. (2014). University spin-offs and the "performance premium". Small Business Economics, 43(2), 309-326.

D'Este, P., \& Perkmann, M. (2011). Why do academics engage with industry? The entrepreneurial university and individual motivations. The Journal of Technology Transfer, 36(3), 316-339.

Dahlman, C. J. (1979). The problem of externality. Journal of Law and Economics, 22(1), 141-162.

Dalziel, M. (2012). A study of business incubators and accelerators in Canada. The evidence network.

Debackere, K., \& Veugelers, R. (2005). The role of academic technology transfer organizations in improving industry science links. Research Policy, 34(3), 321-342.

Degroof, J.-J., \& Roberts, E. B. (2004). Overcoming weak entrepreneurial infrastructures for academic spinoff ventures. Journal of Technology Transfer, 29(3-4), 327-352.

D'Este, P., \& Patel, P. (2007). University-industry linkages in the UK: What are the factors underlying the variety of interactions with industry? Research Policy, 36(9), 1295-1313.

Di Gregorio, D., \& Shane, S. (2003). Why do some universities generate more start-ups than others? Research Policy, 32(2), 209-227.

Ding, W., \& Choi, E. (2011). Divergent paths to commercial science: A comparison of scientists' founding and advising activities. Research Policy, 40(1), 69-80.

Djokovic, D., \& Souitaris, V. (2008). Spinouts from academic institutions: A literature review with suggestions for further research. Journal of Technology Transfer, 33(3), 225-247.

Downs, A. (1957). An economic theory of political action in a democracy. Journal of Political Economy, $65(2), 135-150$.

Doyle, J. C., Low, S. H., Carlson, J. M., Paganini, F., Vinnicombe, G., Willinger, W., et al. (2003). Robustness and the internet: Theoretical foundations.

Druilhe, C., \& Garnsey, E. (2004). Do academic spin-outs differ and does it matter? Journal of Technology Transfer, 29(3-4), 269-285.

Ensley, M. D., \& Hmieleski, K. M. (2005). A comparative study of new venture top management team composition, dynamics and performance between university-based and independent start-ups. $R e$ search Policy, 34(7), 1091-1105. 
Etzkowitz, H. (2003). Research groups as 'quasi-firms': The invention of the entrepreneurial university. Research Policy, 32, 109-121.

Etzkowitz, H., \& Klofsten, M. (2005). The innovating region: Toward a theory of knowledge-based regional development. R\&D Management, 35(3), 243-255.

Fang, S.-C., Tsai, F.-S., \& Lin, J. L. (2010). Leveraging tenant-incubator social capital for organizational learning and performance in incubation programme. International Small Business Journal, 28(1), 90-113.

Feldman, M. P., Link, A. N., \& Siegel, D. S. (2002). The economics of science and technology: An overview of initiatives to foster innovation, entrepreneurship, and economic growth. Boston: Kluwer.

Fini, R., Grimaldi, R., Santoni, S., \& Sobrero, M. (2011). Complements or substitutes? The role of universities and local context in supporting the creation of academic spin-offs. Research Policy, 40(8), 1113-1127.

Fini, R., Grimaldi, R., \& Sobrero, M. (2009). Factors fostering academics to start up new ventures: An assessment of Italian founders' incentives. Journal of Technology Transfer, 34(4), 380-402.

Fini, R., Lacetera, N., \& Shane, S. (2010). Inside or outside the IP system? Business creation in academia. Research Policy, 39(8), 1060-1069.

Fini, R., \& Toschi, L. (2016). Academic logic and corporate entrepreneurial intentions: A study of the interaction between cognitive and institutional factors in new firms. International Small Business Journal, 34(5), 637-659.

Foltz, J., Barham, B., \& Kim, K. (2000). Universities and agricultural biotechnology patent production. Agribusiness, 16(1), 82-95.

Fontes, M. (2005). The process of transformation of scientific and technological knowledge into economic value conducted by biotechnology spin-offs. Technovation, 25(4), 339-347.

Franklin, S. J., Wright, M., \& Lockett, A. (2001). Academic and surrogate entrepreneurs in university spinout companies. Journal of Technology Transfer, 26(1-2), 127-141.

Franzese, R. J., Jr. (2002). Electoral and partisan cycles in economic policies and outcomes. Annual Review of Political Science, 5(1), 369-421.

Friedman, J., \& Silberman, J. (2003). University technology transfer: Do incentives, management, and location matter? Journal of Technology Transfer, 28(1), 17-30.

Garnsey, E., \& Heffernan, P. (2005). High-technology clustering through spin-out and attraction: The Cambridge case. Regional Studies, 39(8), 1127-1144.

Gast, A. (2015). Blue skies impact. http://www.imperial.ac.uk/about/leadership-and-strategy/president/ writing-and-speeches/autumn-letter-2015/. Accessed 25th Jan 2016.

George, G., Zahra, S., \& Wood, R. (2002). The effects of business-university alliances on innovative output and financial performance: A study of publicly traded biotechnology companies. Journal of Business Venturing, 17, 577-609.

Geuna, A., \& Rossi, F. (2011). Changes to university IPR regulations in Europe and the impact on academic patenting. Research Policy, 40(8), 1068-1076.

Gottschalg, O., \& Zollo, M. (2007). Interest alignment and competitive advantage. Academy of Management Review, 32(2), 418-437.

Grandi, A., \& Grimaldi, R. (2005). Academics' organizational characteristics and the generation of successful business ideas. Journal of Business Venturing, 20(6), 821-845.

Grimaldi, R., Kenney, M., Siegel, D. S., \& Wright, M. (2011). 30 years after Bayh-Dole: Reassessing academic entrepreneurship. Research Policy, 40(8), 1045-1057.

Gulbrandsen, M., \& Smeby, J.-C. (2005). Industry funding and university professors' research performance. Research Policy, 34(6), 932-950.

Gurdon, M. A., \& Samsom, K. J. (2010). A longitudinal study of success and failure among scientist-started ventures. Technovation, 30(3), 207-214.

Haeussler, C., \& Colyvas, J. A. (2011). Breaking the ivory tower: Academic entrepreneurship in the life sciences in UK and Germany. Research Policy, 40(1), 41-54.

Hall, B. H., Mairesse, J., \& Mohnen, P. (2009). Measuring the returns to R\&D. National Bureau of Economic Research.

Harrison, R. T., \& Leitch, C. (2010). Voodoo institution or entrepreneurial university? Spin-off companies, the entrepreneurial system and regional development in the UK. Regional Studies, 44(9), 1241-1262.

Hayter, C. S. (2011). In search of the profit-maximizing actor: Motivations and definitions of success from nascent academic entrepreneurs. Journal of Technology Transfer, 36(3), 340-352.

Henrekson, M., \& Goldfarb, B. (2003). Bottom-up vs. Top-down policies towards the commercialization of university intellectual property. Research Policy, 32(4), 639-658.

Henrekson, M., \& Rosenberg, N. (2001). Designing efficient institutions for science-based entrepreneurship: Lesson from the US and Sweden. Journal of Technology Transfer, 26(3), 207-231. 
Hoppe, H. C., \& Ozdenoren, E. (2005). Intermediation in innovation. International Journal of Industrial Organization, 23(5), 483-503.

Huyghe, A., Knockaert, M., Wright, M., \& Piva, E. (2014). Technology transfer offices as boundary spanners in the pre-spin-off process: The case of a hybrid model. Small Business Economics, 43, 1-19.

Jacob, M., Lundqvist, M., \& Hellsmark, H. (2003). Entrepreneurial transformations in the Swedish University system: The case of Chalmers University of Technology. Research Policy, 32, 1555-1568.

Jaffe, A. B. (1989). Real effects of academic research. The American Economic Review, 79(5), 957-970.

Jain, S., George, G., \& Maltarich, M. (2009). Academics or entrepreneurs? Investigating role identity modification of university scientists involved in commercialization activity. Research Policy, 38(6), 922-935.

Jensen, M. C., \& Meckling, W. H. (1976). Theory of the firm: Managerial behavior, agency costs and ownership structure. Journal of Financial Economics, 3(4), 305-360.

Jensen, R. A., Thursby, J. G., \& Thursby, M. C. (2003). Disclosure and licensing of University inventions: 'The best we can do with the $\mathrm{s}^{* *} \mathrm{t}$ we get to work with'. International Journal of Industrial Organization, 21(9), 1271-1300.

Johansson, M., Jacob, M., \& Hellström, T. (2005). The strength of strong ties: University spin-offs and the significance of historical relations. Journal of Technology Transfer, 30(3), 271-286.

Kaufmann, A., \& Tödtling, F. (2001). Science-industry interaction in the process of innovation: The importance of boundary-crossing between systems. Research Policy, 30(5), 791-804.

Kenney, M., \& Goe, W. R. (2004). The role of social embeddedness in professorial entrepreneurship: A comparison of electrical engineering and computer science at UC Berkeley and Stanford. Research Policy, 33(5), 691-707.

Kenney, M., \& Patton, D. (2009). Reconsidering the Bayh-Dole act and the current University Invention ownership model. Research Policy, 38, 1407-1422.

Kenney, M., \& Patton, D. (2011). Does inventor ownership encourage university research-derived entrepreneurship? A six university comparison. Research Policy, 40(8), 1100-1112.

Klofsten, M., \& Jones-Evans, D. (2000). Comparing academic entrepreneurship in Europe-the case of Sweden and Ireland. Small Business Economics, 14(4), 299-309.

Krabel, S., Siegel, D. S., \& Slavtchev, V. (2012). The internationalization of science and its influence on academic entrepreneurship. Journal of Technology Transfer, 37(2), 192-212.

Kurasaki, K. S. (2000). Intercoder reliability for validating conclusions drawn from open-ended interview data. Field Methods, 12(3), 179-194.

Lacetera, N. (2009). Academic entrepreneurship. Managerial and Decision Economics, 30(7), $443-464$.

Lach, S., \& Schankerman, M. (2004). Royalty sharing and technology licensing in universities. Journal of the European Economic Association, 2(2-3), 252-264.

Landry, R., Amara, N., \& Rherrad, I. (2006). Why are some university researchers more likely to create spin-offs than others? Evidence from Canadian universities. Research Policy, 35(10), 1599-1615.

Langford, C. H., Hall, J., Josty, P., Matos, S., \& Jacobson, A. (2006). Indicators and outcomes of Canadian university research: Proxies becoming goals? Research Policy, 35(10), 1586-1598.

Laukkanen, M. (2003). Exploring academic entrepreneurship: Drivers and tensions of university-based business. Journal of Small Business and Enterprise Development, 10(4), 372-382.

Laursen, K., \& Salter, A. (2004). Searching high and low: What types of firms use universities as a source of innovation? Research Policy, 33(8), 1201-1215.

Leeson, P. T., \& Subrick, J. R. (2006). Robust political economy. Review of Austrian Economics, 19(2-3), $107-111$.

Leitch, C. M., \& Harrison, R. T. (2005). Maximising the potential of university spin-outs: The development of second-order commercialisation activities. R\&D Management, 35, 257-272.

Lejpras, A. (2014). How innovative are spin-offs at later stages of development? Comparing innovativeness of established research spin-offs and otherwise created firms. Small Business Economics, 43(2), $327-351$.

Lerner, J. (1999). The government as venture capitalist: The long-run impact of the SBIR program. Journal of Business, 72(3), 55-78.

Leyden, D. P., \& Link, A. N. (2013). Knowledge spillovers, collective entrepreneurship, and economic growth: The role of universities. Small Business Economics, 41(4), 797-817.

Libaers, D., Meyer, M., \& Geuna, A. (2006). The role of university spinout companies in an emerging technology: The case of nanotechnology. Journal of Technology Transfer, 31(4), 443-450.

Lindelof, P., \& Lofsten, H. (2005). Academic versus corporate new technology-based firms in Swedish science parks: An analysis of performance, business networks and financing. International Journal of Technology Management, 31(3-4), 334-357. 
Link, A. N., \& Scott, J. T. (2003). US science parks: The diffusion of an innovation and its effects on the academic missions of universities. International Journal of Industrial Organization, 21(9), 1323-1356.

Link, A. N., \& Scott, J. T. (2005). Opening the ivory tower's door: An analysis of the determinants of the formation of US university spin-off companies. Research Policy, 34(7), 1106-1112.

Link, A. N., \& Siegel, D. S. (2005). Generating science-based growth: An econometric analysis of the impact of organizational incentives on university-industry technology transfer. European Journal of Finance, 11(3), 169-181.

Link, A. N., Siegel, D. S., \& Van Fleet, D. D. (2011). Public science and public innovation: Assessing the relationship between patenting at US National Laboratories and the Bayh-Dole Act. Research Policy, 40(8), 1094-1099.

Link, A. N., Siegel, D. S., \& Wright, M. (2014). The Chicago Handbook of University Technology Transfer and Academic Entrepreneurship.

Lockett, A., \& Wright, M. (2005). Resources, capabilities, risk capital and the creation of university spin-out companies. Research Policy, 34(7), 1043-1057.

Lockett, A., Wright, M., \& Franklin, S. (2003). Technology transfer and universities' spin-out strategies. Small Business Economics, 20, 185-200.

Lundqvist, M. A. (2014). The importance of surrogate entrepreneurship for incubated Swedish technology ventures. Technovation, 34(2), 93-100.

Macho-Stadler, I., Pérez-Castrillo, D., \& Veugelers, R. (2007). Licensing of university inventions: The role of a technology transfer office. International Journal of Industrial Organization, 25(3), 483-510.

Markman, G. D., Phan, P. H., Balkin, D. B., \& Gianiodis, P. T. (2005). Entrepreneurship and universitybased technology transfer. Journal of Business Venturing, 20(2), 241-263.

Martin, S., \& Scott, J. T. (2000). The nature of innovation market failure and the design of public support for private innovation. Research Policy, 29(4), 437-447.

McAdam, M., \& Marlow, S. (2011). Sense and sensibility: The role of business incubator client advisors in assisting high-technology entrepreneurs to make sense of investment readiness status. Entrepreneurship and Regional Development, 23(7-8), 449-468.

Meyer, M. (2006). Academic inventiveness and entrepreneurship: On the importance of start-up companies in commercializing academic patents. Journal of Technology Transfer, 31(4), 501-510.

Meyer-Krahmer, F., \& Schmoch, U. (1998). Science-based technologies: University-industry interactions in four fields. Research Policy, 27(8), 835-851.

Mian, S., Lamine, W., \& Fayolle, A. (2016). Technology business incubation: An overview of the state of knowledge. Technovation, 50-51, 1-12.

Miner, A. S., Gong, Y., Ciuchta, M. P., Sadler, A., \& Surdyk, J. (2012). Promoting university startups: International patterns, vicarious learning and policy implications. Journal of Technology Transfer, $37(2), 213-233$.

Moray, N., \& Clarysse, B. (2005). Institutional change and resource endowments to science-based entrepreneurial firms. Research Policy, 34(7), 1010-1027.

Mosey, S., \& Wright, M. (2007). From human capital to social capital: A longitudinal study of technologybased academic entrepreneurs. Entrepreneurship Theory and Practice, 31(6), 909-935.

Mowery, D. C., \& Sampat, B. N. (2005). The Bayh-Dole act of 1980 and university-industry technology transfer: A model for other OECD governments? In A. N. Link \& F. M. Scherer (Eds.), Essays in honor of Edwin Mansfield (pp. 233-245). Springer. doi:10.1007/0-387-25022-0_18.

Mueller, D. C. (2003). Public choice III. Cambridge: Cambridge University Press.

Mueller, P. (2006). Exploring the knowledge filter: How entrepreneurship and university-industry relations drive economic growth. Research Policy, 35(10), 1499-1588.

Murmann, J. P., \& Frenken, K. (2006). Toward a systematic framework for research on dominant designs, technological innovations, and industrial change. Research Policy, 35(7), 925-952.

Mustar, P., Renault, M., Colombo, M. G., Piva, E., Fontes, M., Lockett, A., et al. (2006). Conceptualising the heterogeneity of research-based spin-offs: A multi-dimensional taxonomy. Research Policy, 35(2), 289-308.

Mustar, P., \& Wright, M. (2010). Convergence or path dependency in policies to foster the creation of university spin-off firms? A comparison of France and the United Kingdom. Journal of Technology Transfer, 35(1), 42-65.

Mustar, P., Wright, M., \& Clarysse, B. (2008). University spin-off firms: Lessons from ten years of experience in Europe. Science and Public Policy, 35(2), 67-80.

Ndonzuau, F. N., Pirnay, F., \& Surlemont, B. (2002). A stage model of academic spin-off creation. Technovation, 22(5), 281-289.

Nerkar, A., \& Shane, S. (2003). When do start-ups that exploit patented academic knowledge survive? International Journal of Industrial Organization, 21(9), 1391-1410. 
Nicolaou, N., \& Birley, S. (2003). Academic networks in a trichotomous categorisation of university spinouts. Journal of Business Venturing, 18(3), 333-359.

O'Shea, R. P., Chugh, H., \& Allen, T. J. (2008). Determinants and consequences of university spinoff activity: A conceptual framework. Journal of Technology Transfer, 33(6), 653-666.

O'Shea, R. P., Allen, T. J., Chevalier, A., \& Roche, F. (2005). Entrepreneurial orientation, technology transfer and spinoff performance of US universities. Research Policy, 34(7), 994-1009.

O'Shea, R. P., Allen, T. J., Morse, K. P., O’Gorman, C., \& Roche, F. (2007). Delineating the anatomy of an entrepreneurial university: The Massachusetts Institute of Technology experience. R\&D Management, $37(1), 1-16$.

Pennington, M. (2011). Robust political economy. Policy: A Journal of Public Policy and Ideas, $27(4), 8$.

Pérez Pérez, M., \& Sánchez, A. M. (2003). The development of university spin-offs: Early dynamics of technology transfer and networking. Technovation, 23(10), 823-831.

Perkmann, M., Tartari, V., McKelvey, M., Autio, E., Broström, A., D’Este, P., et al. (2013). Academic engagement and commercialisation: A review of the literature on university-industry relations. $R e$ search Policy, 42(2), 423-442.

Pirnay, F., Surlemont, B., \& Nlemvo, F. (2003). Toward a typology of university spin-offs. Small Business Economics, 21(4), 355-369. doi:10.2307/40229300.

Powers, J. B., \& McDougall, P. P. (2005). University start-up formation and technology licensing with firms that go public: A resource-based view of academic entrepreneurship. Journal of Business Venturing, 20(3), 291-311.

Rannikko, H. \& Autio E. (2015). Retaining winners: Can policy boost high-growth entrepreneurship? Research policy, ISSN: 0048-7333.

Rasmussen, E. (2006). Two models for university technology transfer operation: Patent agency and 2G. International Journal of Technology Transfer and Commercialisation, 5(4), 291-307.

Rasmussen, E., \& Borch, O. J. (2010). University capabilities in facilitating entrepreneurship: A longitudinal study of spin-off ventures at mid-range universities. Research Policy, 39, 602-612.

Rasmussen, E., \& Gulbrandsen, M. (2012). Government support programmes to promote academic entrepreneurship: A principal-agent perspective. European Planning Studies, 20, 527-546.

Rasmussen, E., Moen, O., \& Gulbrandsen, M. (2006). Initiatives to promote commercialization of university knowledge. Technovation, 26, 518-533.

Rasmussen, E., Mosey, S., \& Wright, M. (2011). The evolution of entrepreneurial competencies: A longitudinal study of university spin-off venture emergence. Journal of Management Studies, 48(6), 1314-1345.

Rogers, E. M., Yin, J., \& Hoffmann, J. (2000). Assessing the effectiveness of technology transfer offices at US research universities. The Journal of the Association of University Technology Managers, 12(1), 47-80.

Romer, P. M. (1990). Endogenous technological change. Journal of Political Economy, 98(5), S71-S102.

Rothaermel, F. T., Agung, S. D., \& Jiang, L. (2007). University entrepreneurship: A taxonomy of the literature. Industrial and Corporate Change, 16(4), 691-791.

Rothaermel, F. T., \& Thursby, M. (2005a). Incubator firm failure or graduation? The role of university linkages. Research Policy, 34(7), 1076-1090.

Rothaermel, F. T., \& Thursby, M. (2005b). University-incubator firm knowledge flows: Assessing their impact on incubator firm performance. Research Policy, 34(3), 305-320.

Sabatier, P. A. (1986). Top-down and bottom-up approaches to implementation research: A critical analysis and suggested synthesis. Journal of Public Policy, 6(01), 21-48.

Salter, A. J., \& Martin, B. R. (2001). The economic benefits of publicly funded basic research: A critical review. Research Policy, 30(3), 509-532.

Shane, S. (2002). Selling university technology: Patterns from MIT. Management Science, 48(1), $122-137$.

Shane, S. (2004a). Encouraging university entrepreneurship? The effect of the Bayh-Dole act on university patenting in the United States. Journal of Business Venturing, 19(1), 127-151.

Shane, S. A. (2004b). Academic entrepreneurship: University spinoffs and wealth creation. Cheltenham: Edward Elgar.

Siegel, D. S., Veugelers, R., \& Wright, M. (2007). Technology transfer offices and commercialization of university intellectual property: Performance and policy implications. Oxford Review of Economic Policy, 23(4), 640-660.

Siegel, D. S., Waldman, D., \& Link, A. (2003a). Assessing the impact of organizational practices on the relative productivity of university technology transfer offices: An exploratory study. Research Policy, $32(1), 27-48$. 
Siegel, D. S., Westhead, P., \& Wright, M. (2003b). Assessing the impact of university science parks on research productivity: Exploratory firm-level evidence from the United Kingdom. International Journal of Industrial Organization, 21(9), 1357-1369.

Smith, H. L., \& Ho, K. (2006). Measuring the performance of Oxford University, Oxford Brookes University and the government laboratories' spin-off companies. Research Policy, 35(10), 1554-1568.

Steffensen, M., Rogers, E. M., \& Speakman, K. (2000). Spin-offs from research centers at a research university. Journal of Business Venturing, 15(1), 93-111.

Stephan, A. (2014). Are public research spin-offs more innovative? Small Business Economics, 43, 1-16.

Stuart, T. E., \& Ding, W. W. (2006). When do scientists become entrepreneurs? The social structural antecedents of commercial activity in the academic life sciences. American Journal of Sociology, 112(1), 97-144.

Takalo, T., \& Tanayama, T. (2010). Adverse selection and financing of innovation: Is there a need for R\&D subsidies? Journal of Technology Transfer, 35(1), 16-41.

Taner, O. (2013) Business incubators in metropolitan Los Angeles: Job creators or boondoggles? Research and Policy Brief Number, 14 Apr 2013.

Thursby, J., Fuller, A. W., \& Thursby, M. (2009). US faculty patenting: Inside and outside university. Research Policy, 38(1), 14-15.

Thursby, J., Jensen, R., \& Thursby, M. C. (2001). Objectives, characteristics and outcomes of university licensing: A survey of major US universities. Journal of Technology Transfer, 26, 59-72.

Thursby, J. G., \& Kemp, S. (2002). Growth and productive efficiency of university intellectual property licensing. Research Policy, 31(1), 109-124.

Thursby, J., \& Thursby, M. C. (2002). Who is selling the ivory tower? Sources of growth in university licensing. Management Science, 48, 90-104.

Thursby, J. G., \& Thursby, M. C. (2011). Has the Bayh-Dole act compromised basic research? Research Policy, 40(8), 1077-1083.

Toole, A. A., \& Czarnitzki, D. (2007). Biomedical academic entrepreneurship through the SBIR program. Journal of Economic Behavior and Organization, 63(4), 716-738.

Toole, A. A., \& Czarnitzki, D. (2009). Exploring the relationship between scientist human capital and firm performance: The case of biomedical academic entrepreneurs in the SBIR program. Management Science, 55(1), 101-114.

Toole, A. A., \& Czarnitzki, D. (2010). Commercializing science: Is there a university "brain drain" from academic entrepreneurship? Management Science, 56(9), 1599-1614.

Tullock, G. (1989). The economics of special privilege and rent seeking (Vol. 5). New York: Springer.

van Burg, E., Romme, A. G. L., Gilsing, V., \& Reymen, I. M. M. (2008). Creating University spin-offs: A science-based design perspective. Journal of Product Innovation Management, 25(2), 114-128.

Van Geenhuizen, M., \& Soetanto, D. P. (2009). Academic spin-offs at different ages: A case study in search of key obstacles to growth. Technovation, 29(10), 671-681.

Vohora, A., Wright, M., \& Lockett, A. (2004). Critical junctures in the development of university high-tech spinout companies. Research Policy, 33(1), 147-175.

Walter, A., Auer, M., \& Ritter, T. (2006). The impact of network capabilities and entrepreneurial orientation on university spin-off performance. Journal of Business Venturing, 21(4), 541-567.

Wennberg, K., Wiklund, J., \& Wright, M. (2011). The effectiveness of university knowledge spillovers: Performance differences between university spinoffs and corporate spinoffs. Research Policy, 40(8), $1128-1143$.

Wieser, R. (2005). Research and development productivity and spillovers: Empirical evidence at the firm level. Journal of Economic Surveys, 19(4), 587-621.

Wright, M. (2014). Academic entrepreneurship, technology transfer and society: Where next? Journal of Technology Transfer, 39(3), 322-334.

Wright, M., Birley, S., \& Mosey, S. (2004). Entrepreneurship and university technology transfer. Journal of Technology Transfer, 29(3/4), 235-246.

Wright, M., Clarysse, B., Lockett, A., \& Knockaert, M. (2008). Mid-range universities' linkages with industry: Knowledge types and the role of intermediaries. Research Policy, 37(8), 1205-1223.

Wright, M., Clarysse, B., Mustar, P., \& Lockett, A. (Eds.). (2007). Academic entrepreneurship in Europe. Cheltenham: Edward Elgar.

Wright, B., Lei, Z., \& Merrill, S. (2014). Industry-funded academic inventions boost innovation. Nature, 507, 297-299.

Wright, M., Lockett, A., Clarysse, B., \& Binks, M. (2006). University spin-out companies and venture capital. Research Policy, 35(4), 481-501. 
Yu, J., \& Nijkamp, P. (2009). Methodological challenges and institutional barriers in the use of experimental method for the evaluation of business incubators: Lessons from the US, EU and China. Paper presented at the Atlanta conference on science and research policy.

Zahra, S. A., Van de Velde, E., \& Larraneta, B. (2007). Knowledge conversion capability and the performance of corporate and university spin-offs. Industrial and Corporate Change, 16(4), 569-608.

Zhang, J. (2009). The performance of university spin-offs: An exploratory analysis using venture capital data. The Journal of Technology Transfer, 34(3), 255-285.

Zucker, L. G., Darby, M. R., \& Armstrong, J. F. (2002). Commercializing knowledge: University science, knowledge capture, and firm performance in biotechnology. Management Science, 48(1), 138-153. 